\title{
Negative Elongation Factor E
}

National Cancer Institute

\section{Source}

National Cancer Institute. Negative Elongation Factor E. NCI Thesaurus. Code C140314.

Negative elongation factor $\mathrm{E}(380 \mathrm{aa}, \sim 43 \mathrm{kDa}$ ) is encoded by the human NELFE gene.

This protein is involved in RNA binding and the regulation of transcript elongation. 